\title{
Ammonium regeneration by microplankton in an upwelling environment
}

\author{
Trevor A. Probyn \\ Marine Biology Research Institute, University of Cape Town, Rondebosch 7700, Cape Town, South Africa
}

\begin{abstract}
Size-fractionated measurements of ammonium flux in the southern Benguela upwelling system provided evidence that regeneration by microplankton $(<200 \mu \mathrm{m})$ was concentrated in the upper water column and generally supported the majority of phytoplankton demands. Based on the present study and literature data it was demonstrated that ammonium remineralization was dependent on the concentration of particulate nitrogen present when viewed on a broad scale. The $<15 \mu \mathrm{m}$ size class, including bacteria and nanoflagellates, proved to be the predominant mineralizers accounting for $95 \%$ of total microplankton regeneration on average. Although ammonification by heterotrophic picoplankton (presumably mainly bacterial) was important in some instances, bacterivorous nanoflagellates ( 1 to $15 \mu \mathrm{m}$ ) appeared to supply the bulk of microplankton excretion, i.e. a mean of $87 \%$ in surface waters and $55 \%$ near the base of the euphotic zone. Bacteria were relatively more active at depth than at the surface although in the majority of cases absolute rates were fastest in surface waters. The possibility exists that bacterial remineralization was underestimated in the $<1 \mu \mathrm{m}$ fraction due to the absence of nanoflagellates during the incubation. Nevertheless, nanoflagellate feeding comprises an essential component of the remineralization process. Ammonium uptake by the different size classes was directly proportional to chlorophyll a concentrations. Results of this study are consistent with the proposed crucial role for small protozoans as intermediaries between bacteria and higher trophic levels and as mineralizers of nutrients for primary producers.
\end{abstract}

\section{INTRODUCTION}

Since the introduction of the concept of 'new' and 'regenerated' production in stratified surface waters (Dugdale \& Goering 1967) it has become increasingly evident that a considerable proportion of primary production is based upon epipelagically excreted nutrients as opposed to nutrients introduced from deeper waters. Eppley \& Petersen (1979) have demonstrated that broad oceanographic regions can be distinguished from each other by the proportion of 'regenerated' primary production occurring there. Whereas in the global ocean as much as $80 \%$ of primary production is estimated to be supported by 'regenerated' nutrients, in productive coastal upwelling environments this figure is about $50 \%$ or less. Nevertheless, absolute regeneration rates and primary production are likely to show synchronous trends. One can therefore expect a concurrent increase in the activities of the organisms responsible for regenerative flux with the increase in primary production due to elevated inputs of 'new' nutrients via upwelling (Harrison 1980). Coastal upwelling thus provides a favourable system for studying epipelagic nutrient regeneration and implicit trophodynamics especially considering the important role these play in extending the impact of the original input of 'new' nutrients.

The distinction between 'new' and 'regenerated' production is largely a distinction between physically and biologically mediated supplies of nutrients for primary production. Although there is a scarcity of information of the actual rates involved, the physical processes controlling the injection of nutrients to the photic layer are better understood than the roles of different planktonic organisms in nutrient recycling. Since the pioneering studies of Harris (1959) a considerable amount of information has accumulated on nutrient excretion by the larger zooplankton species which could effectively be isolated from the phytoplankton community (i.e. $>200 \mu \mathrm{m}$ ). The recent picture that is emerging, however, is that meso- and macrozooplankton are not as important in nutrient regeneration as was originally thought and rarely account for more than $30 \%$ of phytoplankton demands (see reviews by Harrison 1980, Williams 1981, Bidigare 1983). Johannes (1965), using phosphorus as an exam- 
ple, was first to suggest that marine Protozoa were considerably more important than the macrofauna in nutrient excretion. Recently, with the application of the isotope dilution technique to marine plankton studies, it has become possible to perform direct measurements of nutrient excretion by natural assemblages of microorganisms. A number of these studies extending over a wide geographical range have demonstrated for both nitrogen (Harrison 1978, Caperon et al. 1979, Glibert 1982, Koike et al. 1982) and phosphorus (Harrison 1983) that microheterotrophs $<200 \mu \mathrm{m}$, including protozoans (e.g. tintinnid ciliates, microflagellates), metazoans (e.g. developmental stages of copepods) and bacteria supply the major share of uptake requirements. As discussed by Goldman \& Caron (1985) the high assimilation efficiencies (low regeneration efficiencies) typical of each grazing step at the microbial level necessitate a close interrelationship between nutrient regeneration and the structure of the food chain. Thus an 'open' system with a large input of 'new' nutrients will be characterised by a simpler and shorter food chain than one dependent largely on 'regenerated' nutrients and hence a number of regenerating steps.

The aim of this study is to establish the vertical distribution of ammonium regeneration in the upper water column and to identify important classes of arganisms involved using size fractionation techniques. The size fractions are treated as inclusive classes rather than size intervals. The predominant heterotrophs in the size fractions are considered to be bacteria in the $<1 \mu \mathrm{m}$ size class, bacteria and nanoflagellates in the $<3 \mu \mathrm{m}$ and $<15 \mu \mathrm{m}$ size classes, and bacteria, nanoflagellates, dinoflagellates and large ciliates in the $<200 \mu \mathrm{m}$ size class.

\section{METHODS}

Sampling. Ammonium regeneration and uptake were measured on 4 cruises during December 1983, October 1984, March 1985 and July 1985 aboard the research vessels 'Africana' and 'Sardinops' off the west coast of South Africa. All stations sampled were over the shelf area with the exception of Stn 1 which was located in deeper oceanic waters (Fig. 1). Samples were taken using plastic Niskin bottles or, in the case of surface water, a bucket. Water from the surface and either the $1 \%$ light level $(3 \times$ Secchi depth) or the thermocline region were used in the size-fractionation experiments. These samples were incubated in simulated in situ deck boxes at either 100 or $1 \%$ surface irradiance. Samples for measurement of depth profiles of ammonium regeneration were incubated in the dark. All incubation bottles were cooled by flowing

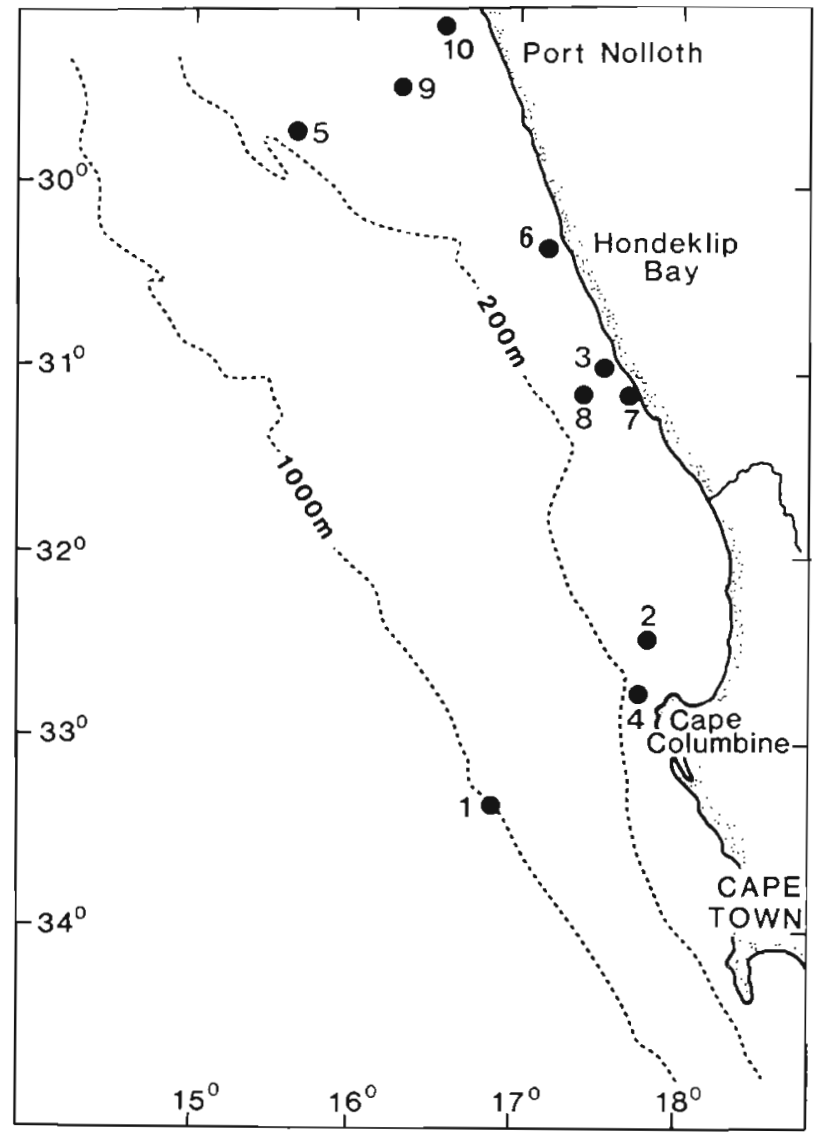

Fig. 1. Station locations for the ammonium flux measurements in the southern Benguela region

surface seawater. Temperature data were obtained from continuous profiles using the ship's CTD system aboard the 'Africana'.

Analytical. Particulate matter for each size fraction was concentrated onto glass fibre filters (Whatman GF/ $F$ filters were used throughout) and frozen for later analyses. Chlorophyll a was measured according to Jeffrey \& Humphrey (1975) and particulate nitrogen on a Heraeus CHN analyser. Ammonium concentrations were determined in triplicate according to the manual method described in Grasshoff (1976) scaled down to $5 \mathrm{ml}$. With the exception of Stns 3 and 4 ammonium concentrations were determined immediately after addition of the ${ }^{15} \mathrm{~N}$ tracer. Samples for these 2 stations were frozen and analysed about a week later.

Phytoplankton and microheterotroph counts. Samples for counting were preserved in $1 \%$ Lugol's iodine. Bacteria were counted in thiosulphate-cleared samples using the fluorochrome acridine orange (Hobbie et al. 1977). Six different classes of bacteria were identified according to size and shape, and total bacterial biomass was calculated from the cell volumes of each class (Painting et al. 1985) using a specific gravity of $1.1 \mathrm{~g} \mathrm{~cm}^{-3}$ (Doetsch \& Cook 1973). Phytoplankton, 
tintinnid ciliates and nanoflagellates were counted using an inverted microscope. Ciliates other than tintinnids were not frequently observed. No distinction was made between chlorotic and apochlorotic nanoflagellates. Recent evidence indicates that the presence of an active chloroplast in oceanic flagellates does not necessarily preclude phagotrophy (Estep et al. 1986).

Ammonium flux experiments. All water used in the ${ }^{15} \mathrm{~N}$ experiments was pre-screened through a $200 \mu \mathrm{m}$ plankton net. Further size fractionation was through either a $15 \mu \mathrm{m}$ net, a $3 \mu \mathrm{m}$ Nuclepore filter or a $1 \mu \mathrm{m}$ Nuclepore filter. Following this $2 \mathrm{l}$ was measured out and spiked with $0.2 \mu \mathrm{mol}{ }^{15} \mathrm{NH}_{4} \mathrm{Cl}(99.7 \%)$ and the sample split. One half was decanted into a $1 \mathrm{l}$ glass bottle and placed immediately in an incubator. The other half was filtered under vacuum and a portion of the filtrate used for ammonium analyses. Exactly $900 \mathrm{ml}$ of the filtrate was spiked with $10 \mu \mathrm{mol} \mathrm{NH}_{4} \mathrm{Cl}$ to satisfy the mass requirements for atomic spectroscopy and stored frozen. Incubations lasted 4 to $8 \mathrm{~h}$ and were generally centred around midday.

Experiments were terminated by filtration (Whatman $G F / F)$ and the filters frozen after rinsing with $50 \mathrm{ml} 0.2 \mu \mathrm{m}$ filtered seawater. The filtrate was used for ammonium determinations and $900 \mathrm{ml}$ for determination of the aqueous ammonium enrichment was stored frozen as before. Aqueous ammonium was recovered by diffusion. Sufficient $\mathrm{MgO}$ was added to the thawed sample to raise the $\mathrm{pH}$ above 9 . A $25 \mathrm{~mm}$ glass fibre filter wetted with $0.05 \mathrm{mi}$ oN $\mathrm{H}_{2} \mathrm{SO}_{4}$ was then suspended above the sample and the bottle capped tightly. The bottles were left at room temperature for about 2 wk during which time generally in excess of $50 \%$ of the aqueous ammonium was recovered on the filter. The speed and efficiency of recovery can be greatly improved by continual stirring throughout the recovery period. The filters were shaken in $5 \mathrm{ml}$ double-distilled-deionised water and an aliquot removed for colorimetric determination of ammonium content. Enrichment with ${ }^{15} \mathrm{~N}$ was determined by atomic emission spectroscopy according to a Rittenberg oxidation procedure (Fielder \& Proksch 1976). Particulate ${ }^{15} \mathrm{~N}$ enrichment was determined in a similar manner following Kjeldahl digestion and distillation.

Ammonium uptake rates $(\mathrm{u})$ were calculated using the following equation in which correction is made for isotopic dilution (Glibert et al. 1982a):

$$
\mathrm{u}=\frac{\mathrm{PE} \times \mathrm{PN}}{\mathrm{R} \times \mathrm{T}}
$$

where $P E=$ percent ${ }^{15} \mathrm{~N}$ enrichment of the particulate fraction in excess of the natural abundance; PN = particulate nitrogen concentration $\left(\mu \mathrm{mol} \mathrm{^{-1 }}\right) ; \mathrm{T}=$ duration of the incubation; and $\mathrm{R}=$ exponential aver- age aqueous ${ }^{15} \mathrm{~N}$ enrichment: $\mathrm{R}=\mathrm{Ro} / \mathrm{kT}\left(1-\mathrm{e}^{-\mathrm{kT}}\right)$ where $k=\frac{-\ln R t / R o}{T}$ and Ro and Rt are the measured aqueous ${ }^{15} \mathrm{~N}$ enrichments at the beginning and end of an incubation.

Ammonium regeneration rates were calculated from a modified form of the Blackburn (1979) and Caperon et al. (1979) model:

$$
r=\frac{\ln (\mathrm{Rt} / \mathrm{Ro})}{\ln (\mathrm{St} / \mathrm{So})} \cdot \frac{(\mathrm{So}-\mathrm{St})}{\mathrm{T}}
$$

where So and St $=$ aqueous ammonium concentrations at the start and finish of an experiment. In cases where ammonium concentrations remained unchanged over the time course of an experiment (measured concentrations within $0.02 \mu \mathrm{mol} \mathrm{l}^{-1}$ at ammonium concentrations $<1 \mathrm{~mol} \mathrm{I}^{-1}$ ) regeneration rates were calculated from the equation of Laws (1984):

$$
\mathrm{r}=\frac{\ln (\mathrm{Ro} / \mathrm{Rt}) \mathrm{So}}{\mathrm{T}}
$$

Statistical. Curves were computer fitted to untransformed data by a least squares iterative process (STATPRO statistical package). The best fit of either an exponential or power function was selected on the basis of minimizing the residual sum of squares. The power function proved to give the better fit of the two. Goodness of fit $\left(\mathrm{r}^{2}\right)$ was calculated from a semilogarithmic plot of the data. Analysis of covariance was used in the test for coincidental linear regressions.

\section{RESULTS}

\section{Microscopical examination}

Inverted microscope counts of the numerically important taxa at 4 of the stations sampled for the size fractionation studies are shown in Table 1 . The netplankton fraction (200 to $15 \mu \mathrm{m}$ ) was dominated by the diatoms Nitzschia spp., Chaetoceros spp., and Asterionella glacialis. Heterotrophic dinoflagellates and tintinnids were also common in this size class. Copepod nauplii were observed very infrequently. The nanoplankton $(<15 \mu \mathrm{m})$ was comprised mainly of numerically dominant flagellates. On average $69 \pm$ $7 \%(95 \%$ confidence limits, $n=14)$ of these nanoflagellates were $<5 \mu \mathrm{m}$. This ratio was apparently not affected by sample depth.

There was a general tendency for bacterial biomass to be greater in surface waters (Fig. 2), in agreement with previous studies off the southeast coast of England (Joint \& Pomroy 1983, Holligan et al. 1984a) and the southern Benguela region (Lucas et al. 1986). Bacterial biomass at the oceanic site (Stn 1) was smaller than over the shelf. 
Table 1. Densities (cells $\mathrm{ml}^{-1}$ ) of the numerically important taxa at 4 of the stations in the southern Benguela region

\begin{tabular}{|c|c|c|c|c|c|c|c|c|}
\hline \multirow[t]{2}{*}{ Species } & \multicolumn{2}{|c|}{ Stn 5} & \multicolumn{2}{|c|}{$\operatorname{Stn} 6$} & \multicolumn{2}{|c|}{$\operatorname{Stn} 7$} & \multicolumn{2}{|c|}{ Stn 9} \\
\hline & $0 \mathrm{~m}$ & $27 \mathrm{~m}$ & $0 \mathrm{~m}$ & $12 \mathrm{~m}$ & $0 \mathrm{~m}$ & $28 \mathrm{~m}$ & $0 \mathrm{~m}$ & $35 \mathrm{~m}$ \\
\hline \multicolumn{9}{|l|}{ Diatoms } \\
\hline Nitzschia seriata & 1.5 & 1.2 & 1068.6 & 814.3 & & & 7.5 & 0.1 \\
\hline N. closterium & 0.4 & & & & & 2.3 & 4.8 & \\
\hline N. delicatissima & & & & & & 3.0 & 133.2 & 91.9 \\
\hline Asterionella glacialis & & & & & & & 388.0 & 507.1 \\
\hline Bacteriastrum lyalium & & & & & & & 67.2 & 17.6 \\
\hline Chaetoceros spp. & & & & & & & 5.8 & 8.6 \\
\hline Corethron criophilum & & & 0.9 & 1.0 & & & & \\
\hline Thalassiosira spp. & & & & & 0.4 & 0.2 & & 20.8 \\
\hline \multicolumn{9}{|l|}{ Dinoflagellates } \\
\hline Protoperidium pallidum & & & & & & & 0.4 & \\
\hline Gymnodinum spp. & 3.0 & 2.3 & 0.8 & 1.1 & & & & \\
\hline Scripsiella spp. & 8.7 & 3.7 & & & & & & \\
\hline Small $(<15 \mu \mathrm{m})$ unknown & & & 99.8 & & & & & \\
\hline \multicolumn{9}{|l|}{ Other } \\
\hline Nanoflagellates & 1227.7 & 1015.5 & 1905.2 & 2610.5 & 387.7 & 207.7 & 1776.6 & 1041.6 \\
\hline Tintinnids & 6.1 & 6.9 & 1.4 & 2.7 & & & 7.0 & 5.1 \\
\hline
\end{tabular}

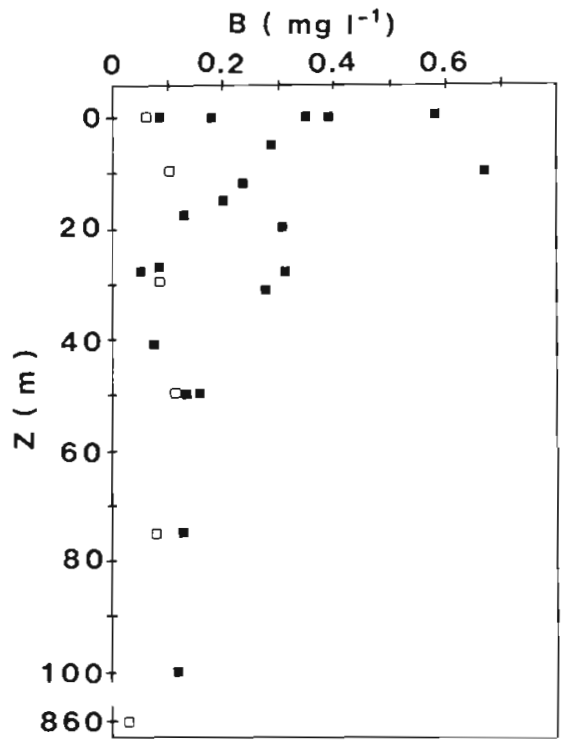

Fig. 2. Combined depth profile of bacterial biomass (B) measured at all stations. Open symbols: oceanic station

\section{Ammonium ụptake}

Ammonium uptake rates for the 4 size fractions are shown in Fig. 3. Data for Stns 5 and 6 are not available as the filters for ${ }^{15} \mathrm{~N}$ determinations were damaged during storage. Uptake rates were higher at the surface than at greater depth. It is clear that the $<15$ um size class frequently accounts for the majority of ammonium uptake; being $72 \%$ on average. In fact a considerable proportion of uptake activity was in the $<3 \mu \mathrm{m}$ size class. Uptake below the euphotic zone

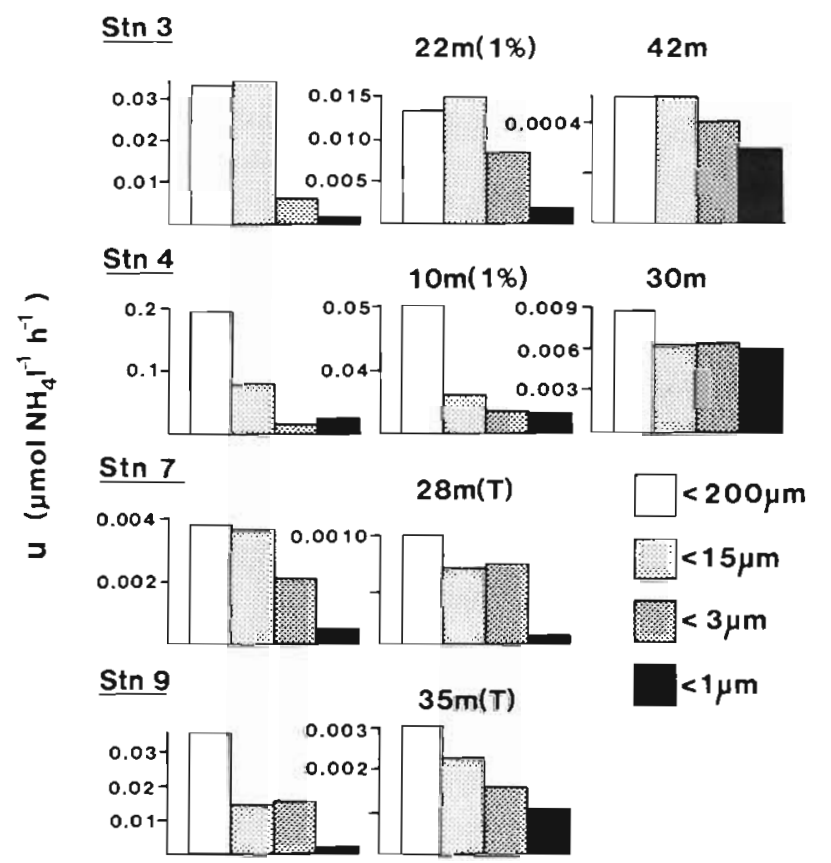

Fig. 3. Size-fractionated ammonium uptake (u) at the surface, the $1 \%$ light level $(1 \%)$, thermocline $(\mathrm{T})$, and the aphotic zone

appeared to be largely bacterial $(<1 \mu \mathrm{m})$. Ammonium uptake rates for each size class generally followed the chlorophyll a values (Fig. 4). There was no statistical difference between the slopes and elevations of the 4 regression equations for the different size classes $(p>0.25)$. The common relation is described by the equation: $\mathrm{u}=0.008 \mathrm{Chl} a-0.001\left(\mathrm{r}^{2}=0.88\right.$, $p<0.001, n=40)$. Eppley et al. (1979) also demons- 


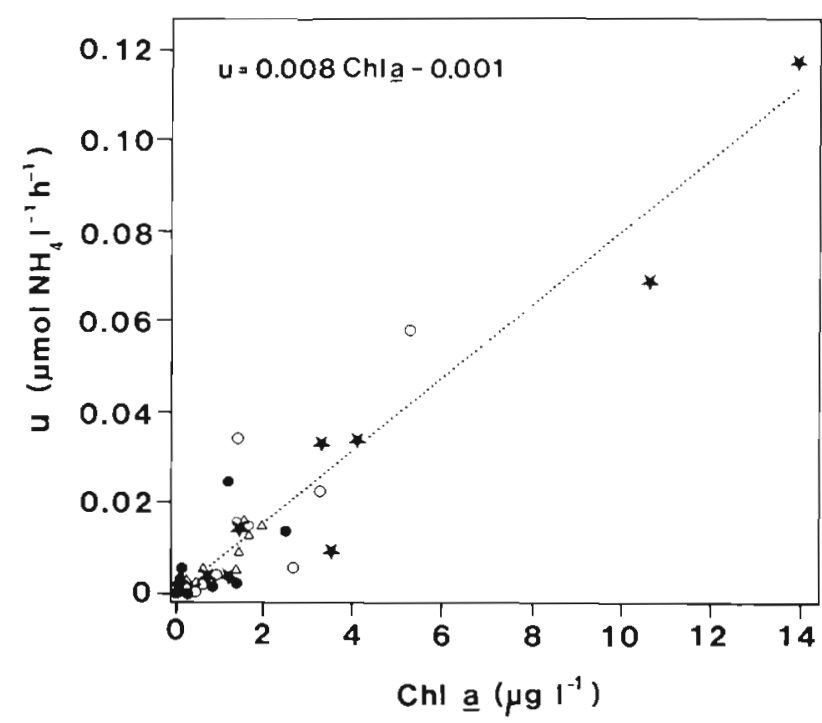

Fig. 4. Relation between ammonium uptake (u) and chlorophyll a concentration for the 4 size fractions: $<200 \mu \mathrm{m}(\star)$, $<15 \mu \mathrm{m}(\bigcirc),<3 \mu \mathrm{m}(\Delta)$, and $<1 \mu \mathrm{m}(\bullet)$

trated an essentially linear relation between chlorophyll $a$ and ammonium assimilation in the Southern Californian Bight.

\section{Ammonium regeneration}

The majority of ammonium regeneration by microplankton at Stns 1, 8 and 10 occurred in the upper water columin above the thermocine (Fig. 5). Maximum regeneration rates at Stns 2 and 7 occurred somewhat deeper and were an order of magnitude slower than for the other stations. Ammonium concentrations, however, reached a maximum at the thermocline (Fig. 5). Since an increase in microplankton regeneration at the thermocline was only evident at the oceanic Stn 2, a likely explanation for the accumulation of ammonium at the thermocline is a reduced demand through light limitation of photosynthesis and/or utilization of alternative nitrogen sources (e.g. nitrate) by primary producers. The present findings, however, do not preclude meso- and macro-zooplankton excretion as contributing significantly to ammonium regeneration in some instances.

As with uptake, ammonium regeneration in the aphotic zone was largely bacterial (Fig. 6). No obvious generalizations can be made about the size structure of the ammonium-regenerating community at the surface and at or near the base of the euphotic zone, although bacteria did appear to be relatively more active with depth. At the surface the $<1 \mu \mathrm{m}$ fraction contributed an average of $11 \%$ (range 1 to $35 \%$ ) to total regeneration while near the base of the euphotic zone it supplied $32 \%$ (range 0 to $79 \%$ ). Absolute regeneration

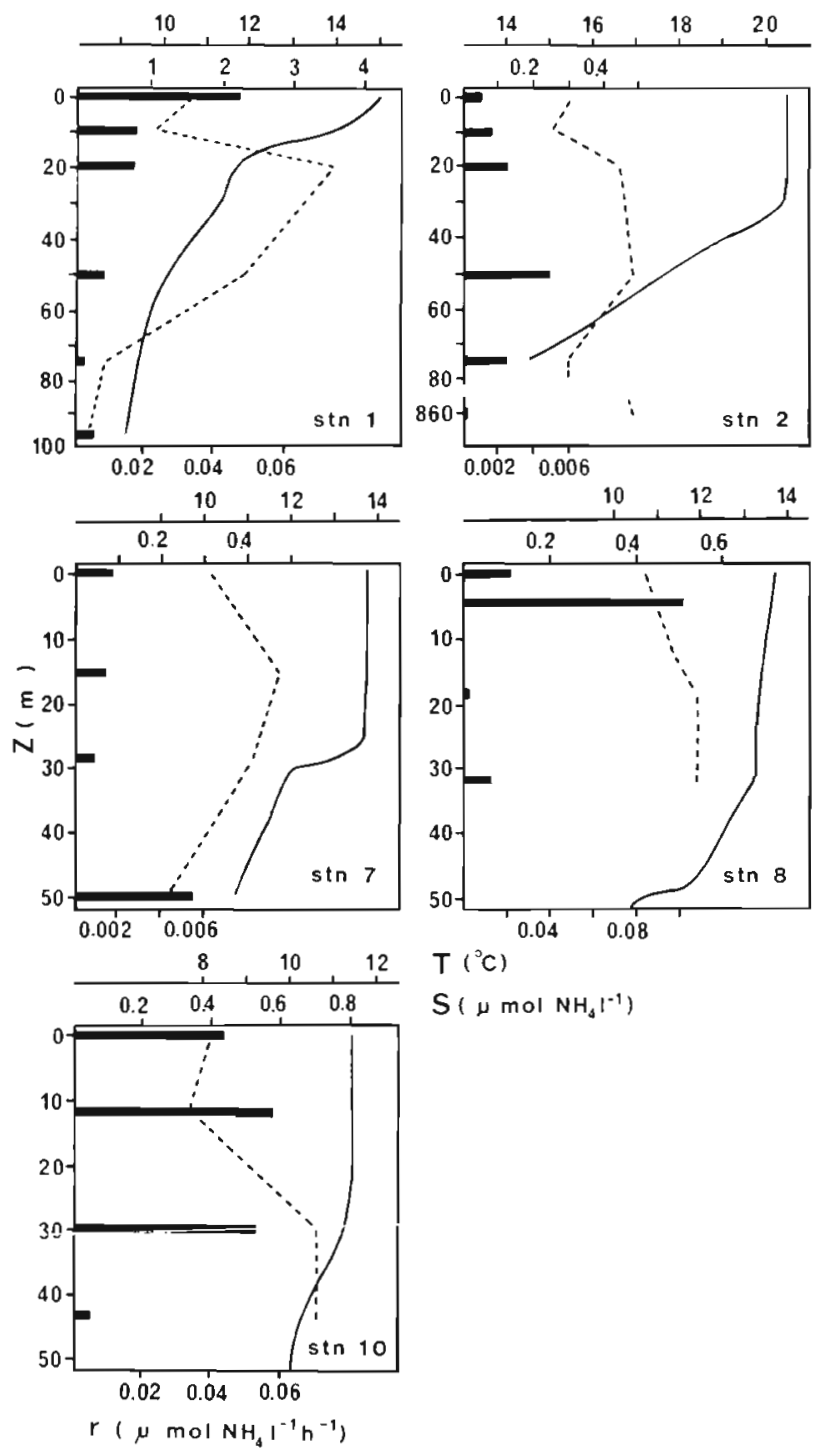

Fig. 5. Depth profiles of ammonium regeneration (r, bars) and ammonium concentration ( $\mathrm{S}$, broken line) in relation to temperature (solid line)

rates for each size class, however, were faster in surface waters, with the exception of Stns 5 and 6 . One unifying trend that does emerge from the data is that the bulk $(93 \%)$ of microplankton ammonium regeneration was by microbes that passed a $15 \mu \mathrm{m}$ screen. Of this some $87 \%$ (range 66 to $99 \%$ ) of the activity was in the 15 to $1 \mu \mathrm{m}$ size interval at the surface and $55 \%$ (range 19 to $90 \%$ ) near the base of the euphotic zone. It is apparent that the nanoflagellate-dominated size class was responsible for a substantial proportion of total microplankton ammonium excretion. Total nanoflagellate counts (Table 1) proved to be closely correlated with ammonium regeneration rates $\left(r^{2}=0.69\right.$, $0.02>p>0.01, n=8$ )

Since the majority of nanoflagellates were close to $3 \mu \mathrm{m}$ size in diameter the apparent enhancement of 


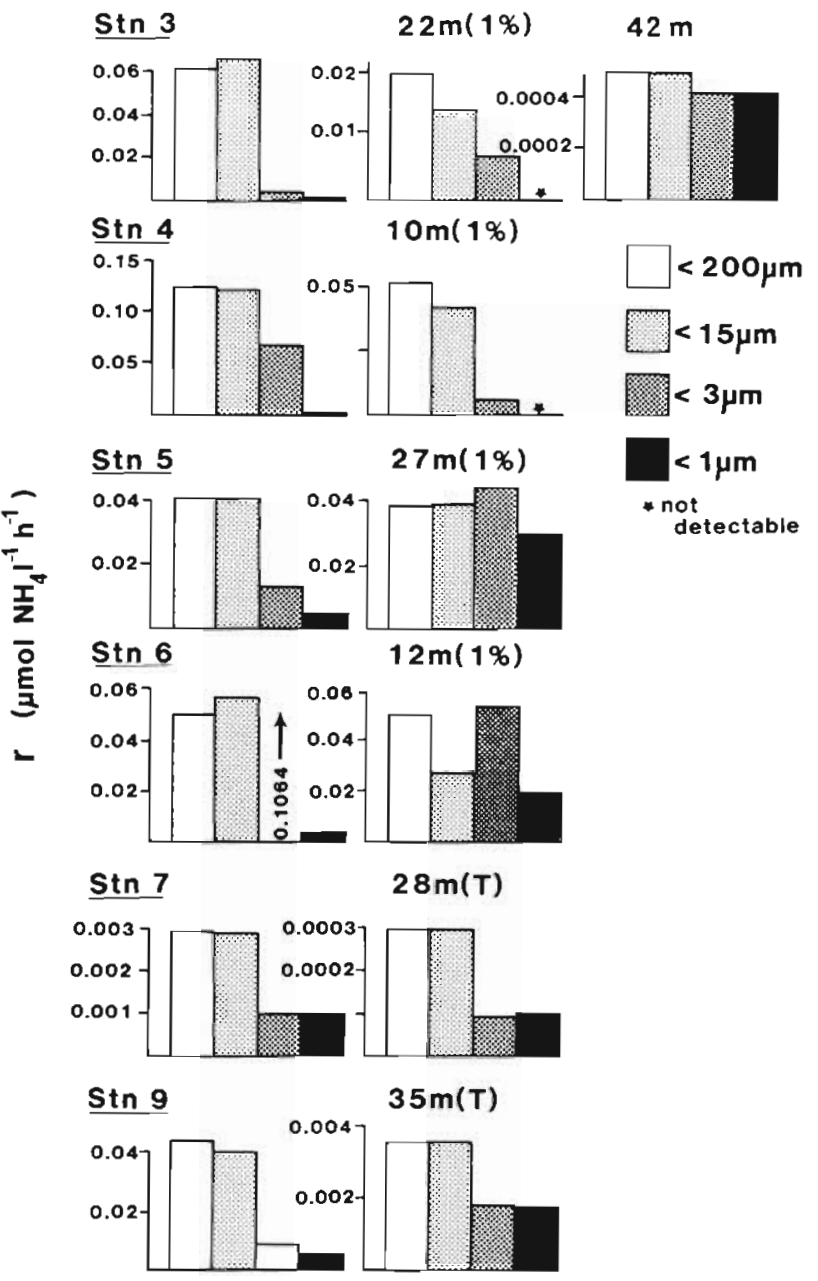

Fig. 6. Size-fractionated ammonium regeneration ( $r$ ) at the surface, the $1 \%$ light level $(1 \%)$, thermocline $(\mathrm{T})$, and the aphotic zone

regeneration for the $<3 \mu \mathrm{m}$ size class for Stn 6 may have resulted from the stimulation of nanoflagellate bacterivory in the absence of their predators after passing through the membrane filter. Alternatively, Ferguson et al. (1984) have shown that filtration of seawater through a $3 \mu \mathrm{m}$ Nuclepore filter resulted in a significant increase in the concentration of dissolved primary amines, presumably as a result of cell rupture. Such an enrichment with dissolved organic matter is likely to stimulate bacterial decomposition and nutrient release.

\section{Assimilation/regeneration ratios}

The relation between ammonium assimilation and regeneration for the various microplankton size classes is shown in Fig. 7. Although appreciable deviations were evident at low rates, assimilation and regeneration were roughly in balance for the entire microplank-

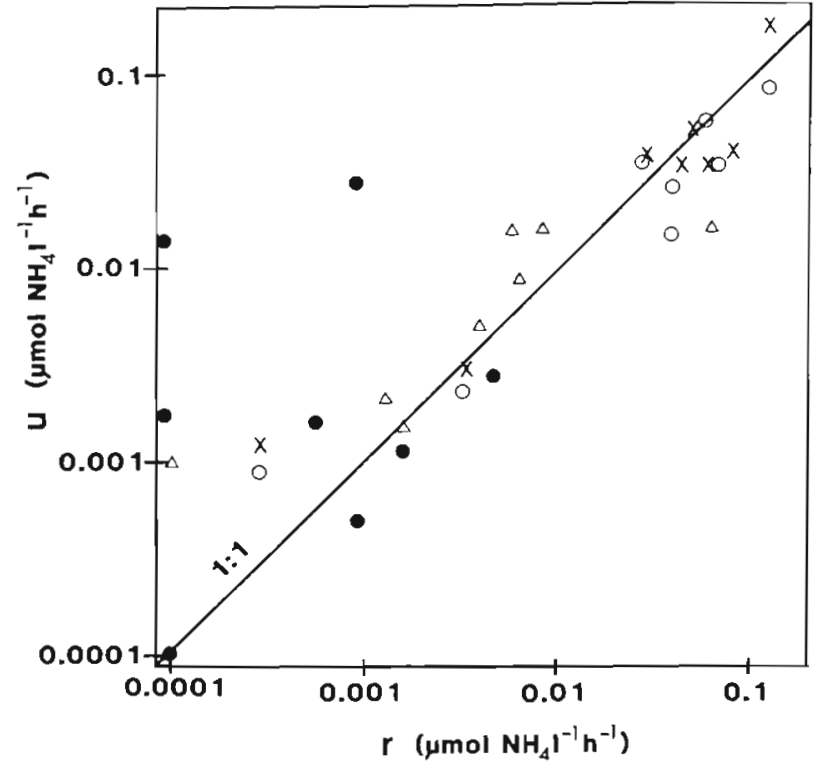

Fig. 7. Relation between ammonium regeneration ( $\mathrm{r}$ ) and uptake (u) in the upper water column for the 4 size fractions: $<200 \mu \mathrm{m}(x),<15 \mu \mathrm{m}(0),<3 \mu \mathrm{m}(\Delta)$, and $<1 \mu \mathrm{m}(\bullet)$. The solid line represents a $1: 1$ relation

ton community $(<200 \mu \mathrm{m})$. Size-related trends were not obvious in these data.

\section{DISCUSSION}

\section{Ammonium assimilation}

This study supports earlier conclusions that the majority of microplankton ammonium assimilation during non-bloom conditions is by nanoplankton $<15 \mu \mathrm{m}$ (Glibert et al. 1982b, Furnas 1983, Probyn 1985). This is illustrated in the seasonal study in Narragansett Bay (Rhode Island, USA: Furnas 1983) where the total phytoplankton community ammonium uptake was dominated by large chain-forming diatoms in the winter-spring and by nanoplankton $(<10 \mu \mathrm{m})$ during the summer. Field measurements of nitrogen resource partitioning indicate ammonium may or may not constitute a similar proportion of the total nitrogen ration for both nanoplankton and the intact phytoplankton community (Furnas 1983, Nalewajko \& Garside 1983, Probyn 1985). However, relative preference indices for ammonium, nitrate and urea suggest that there is no obvious size-related preference for either reduced or oxidised nitrogen by netplankton and nanoplankton (Furnas 1983, Probyn 1985). Picoplankton, however, do utilise proportionally more urea and ammonium than nitrate compared to netplankton and nanoplankton (Probyn 1985). There is evidence to suggest that picoplankton also utilise reduced nitrogen more efficiently (per unit phytoplankton biomass) than 
larger phytoplankton species. Studies in Hawaiian surface waters (Bienfang \& Takahashi 1983), the equatorial Atlantic (Le Bouteiller 1986) and Agulhas Bank waters (Probyn \& Lucas 1987) have demonstrated that ammonium uptake rates as a function of chlorophyll a concentration were faster for picoplankton than nanoplankton or netplankton. This did not appear to be the case in the present study where ammonium uptake rates and chlorophyll a concentrations for the different size fractions shared a common regression line (Fig. 4).

\section{Ammonium assimilation/regeneration}

There is conflicting experimental evidence regarding the time scales over which ammonium fluxes through the microplankton community are coupled. Experiments in the Southern Californian Bight and CEPEX enclosures, British Columbia, demonstrated that ammonium regeneration generally exceeds assimilation over a $24 \mathrm{~h}$ period (Harrison 1978). Similarly, short-term ( 1 to $4 \mathrm{~h}$ ) daytime excretion measurements in such diverse regions as the Scotia Sea, Vineyard Sound, Massachusetts, USA (Glibert 1982) and Bedford Basin, Nova Scotia, Canada (La Roche 1983) indicate, in agreement with the present study, that microplankton regeneration generally equals or exceeds assimilation. It has also been shown experimentally that a steady state can exist between ammonium efflux and uptake even over a period of minutes (Glibert 1982). By way of contrast ammonium assimilation during daylight hours was shown to exceed microplankton regeneration in the Oslofjord, Norway (Paasche \& Kristiansen 1982) and the MidAtlantic Bight (Harrison et al. 1983). These findings, however, can be reconciled with the other studies when one considers that regeneration is likely to exceed assimilation during darkness. This has been demonstrated in Kaneohe Bay, Hawaii (Caperon et al. 1979) and the Sargasso Sea (Glibert 1982). These authors demonstrated that microplankton regeneration and uptake were only in balance when integrated over $24 \mathrm{~h}$ due to the mismatch of fluxes over the light/dark cycle.

Harrison (1978) has shown that both ammonium assimilation and regeneration rates are faster in the euphotic zone than in deeper waters. As was the case in the present study (Fig. 5) assimilation decreased relative to regeneration with depth resulting in an accumulation of ammonium below the $1 \%$ light level. Such a depth-related variation in assimilation/regeneration ratios might result in a marked imbalance in ammonium fluxes at discrete depths. Nevertheless, when integrated over the upper mixed layer, uptake and regeneration will be in balance (Harrison et al.
1983). These findings emphasize that when both the appropriate time and space scales are considered, microplankton excretion probably accounts for most of ammonium demand in the euphotic zone.

\section{Ammonium regeneration}

Large scale spatial variation in remineralization generally follows gradients in primary production (Harrison 1980) and consequently, gradients in particulate matter. Koike et al. (1982) have demonstrated a positive correlation between particulate nitrogen and ammonification in enclosure experiments. Fig. 8 shows

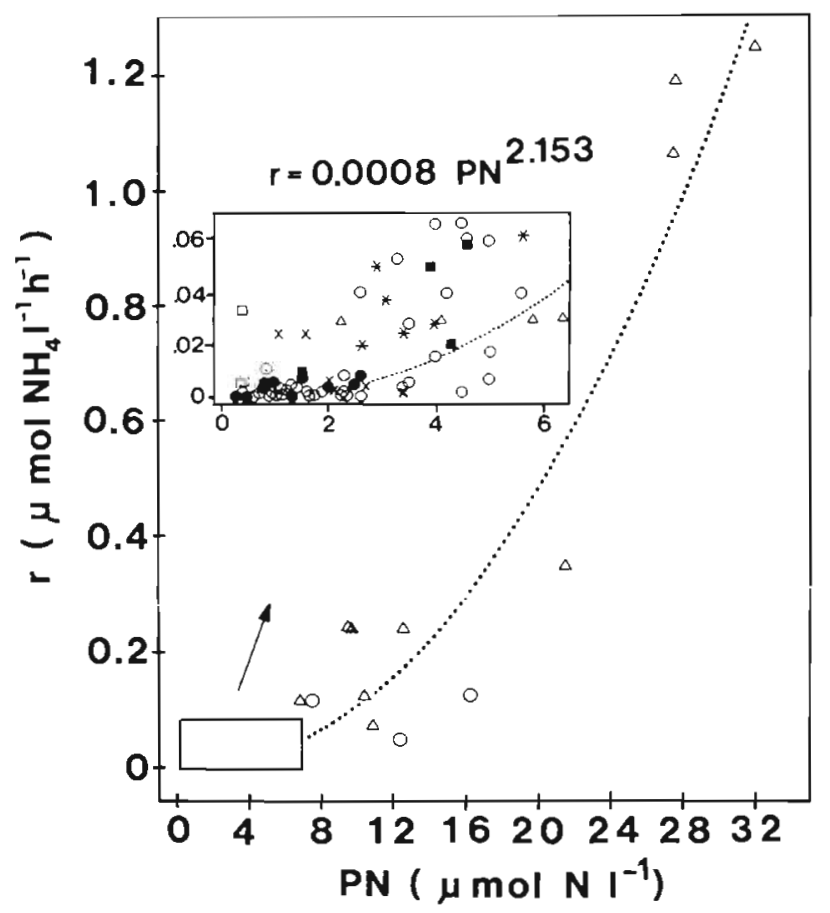

Fig. 8. Relation between ammonium regeneration (r) and particulate nitrogen concentration (PN) for the present study and literature data. $(\Delta)$ Chesapeake Bay; $(\times)$ Scotia Sea; $(\square)$ Sargasso Sea; (a) Kaneohe Bay; (*) CEPEX enclosure; (•) Southern California Bight; $(O)$ this study. Sources of data were Tables 1 \& 2 (Harrison 1978); Tables 1 \& 2 (Caperon et al. 1979); Fig. $9 \& 11$, Tables $2 \& 3$ (Glibert 1982); and Tables $2 \&$ 3 (Glibert et al. 1982a). Size-fractionated data were treated as inclusive size classes rather than size intervals

a compilation of the present data and literature data on particulate nitrogen concentrations and ammonium regeneration rates (Harrison 1978, Caperon et al. 1979, Glibert 1982, Glibert et al. 1982a). The relation between the 2 variables can be described by the power equation: $r=0.0008 \mathrm{PN}^{2.153}\left(\mathrm{r}^{2}=0.52, \mathrm{p}<0.001, \mathrm{n}=\right.$ 91). The nature of the relation indicates that the turnover rate of particulate nitrogen as ammonium 
increases with increasing particulate concentration. It is noteworthy that the fastest regeneration rates reported in the literature $\left(>0.2 \mu\right.$ mole $\left.\mathrm{l}^{-1} \mathrm{~h}^{-1}\right)$ were associated with estuarine environments such as Kaneohe Bay (Caperon et al. 1979), Chesapeake Bay (Glibert 1982) and Bedford Basin (La Roche 1983). The present range of regeneration rates for the shelf region of the southern Benguela are intermediate between those reported for coastal and oligotrophic waters.

This study confirms previous findings in very diverse oceanographic regions that the smaller microplankton (heterotrophic nanoplankton and picoplankton) are generally most important in remineralization (Glibert 1982). The extent to which bacterial decomposition contributes directly to nutrient regeneration in the epipelagial is a contentious issue. Decomposition has been demonstrated to be greatly increased in the presence of protozoan grazers (Barsdate et al. 1974, Fenchel \& Harrison 1976) which through their bacterivorous pursuits, enhance the labile dissolved organic matter pool and thereby stimulate bacterial growth and mineral turnover (Sieburth \& Davis 1982, Taylor et al. 1985). An additional explanation is that bacterivores maintain bacterial populations in a state of 'physiological youth' thereby increasing the assimilation of organic matter (Fenchel \& Harrison 1976). Other laboratory studies, however, suggest that the importance of bacteria in the upper water column is not in remineralization directly but rather as packagers of labile dissolved organic matter into edible particles (Johannes 1965, Azam \& Hodson 1977, Goldman \& Caron 1985). This latter view is particularly appealing considering that bacteria are very efficient immobilisers of dissolved nutrients and have been demonstrated to compete successfully with phytoplankton for this resource (Rhee 1972, Krempin et al. 1981). Field studies employing ${ }^{15} \mathrm{~N}$, however, have shown that microplankton ammonium remineralization may at certain times, such as towards the end of a phytoplankton bloom, be dominated by organisms passing a $1 \mu \mathrm{m}$ filter (Harrison 1978, Glibert 1982, Harrison et al. 1983). Bacterial catabolism of dissolved free amino acids has been shown to be accompanied by a substantial release of ammonium amounting to some $60 \%$ of the total nitrogen regeneration in enclosure experiments (Hollibaugh et al. 1980). For at least one station in the present study, $\operatorname{Stn} 5$, it appears that bacteria may be very effective nitrogen remineralizers on both an absolute and proportional basis. Generally any heterotrophic activity associated with the $<1 \mu \mathrm{m}$ size class is regarded as being primarily bacterial (Azam \& Hodson 1977. Harrison et al. 1977) although the recent demonstration that active eukaryotic bacterivores may be $<0.6 \mu \mathrm{m}$ suggests this might not always be the case (Fuhrman \& McManus 1984, Cynar et al. 1985).
In their model of the euphotic zone and thermocline region Moloney et al. (1986) and Newell et al. (1987) describe a succession of organisms following a pulse of 'new' nutrients, starting with bacteria and leading through nanoflagellates to larger Protozoa and mesozooplankton. Direct remineralization of nutrients by bacteria is postulated to be more important at the thermocline than in surface waters (Newell et al. 1987). The present size fractionation studies provide some support for these ideas on a relative rate basis. Ammonification in the $<1 \mu \mathrm{m}$ fraction contributed on average 3 times more towards total microplankton ammonium regeneration at the base of the euphotic zone and the thermocline than in surface waters. Furthermore, the absolute rates of bacterial ammonification at depth for Stns 5 and 6 were faster than at the surface. Such findings may be related to the breakdown of particulate detritus at the thermocline and dissolved organic matter at the surface as depicted in the 2-layered model of Newell et al. (in press).

Bacterial biomass and ammonium regeneration in this study were similarly distributed through the water column being highest in the surface waters. The corre lation between these 2 variables (Fig. 9) can be described by the power curve: $\mathrm{r}=0.1528 \mathrm{~B}^{1.334}\left(\mathrm{r}^{2}=\right.$ $0.78, \mathrm{p}<0.001, \mathrm{n}=28$ ). Newell et al. (1987) have been able to predict ammonium regeneration at open sea bacterial concentrations using a linear fit to the data shown in Fig. 9 with some degree of success. The shortcomings of such a linear fit would become evident

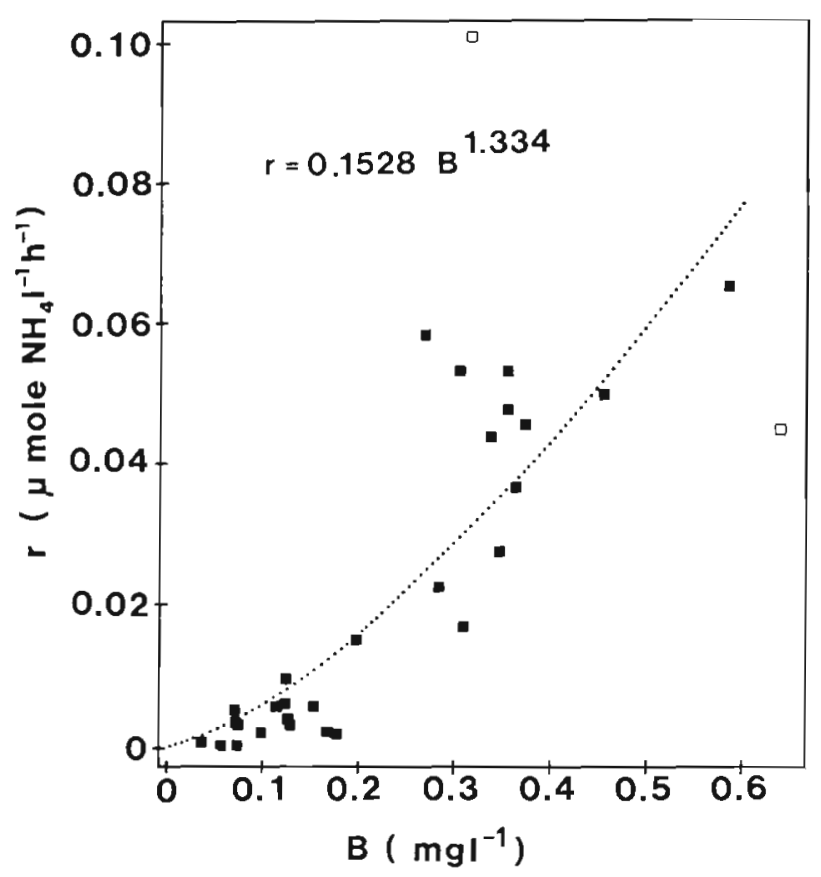

Fig. 9. Relation between ammonium regeneration ( $\mathrm{r}$ ) and bacterial biomass (B). Points represented by open symbols were regarded as outliers and were excluded for curve-fitting 
at the high bacterial biomass typical of coastal waters. This relation, although of limited quantitative significance, does imply that bacterial biomass is at least indirectly important to ammonium regeneration.

The present study, in demonstrating that microbes in the 1 to $15 \mu \mathrm{m}$ size interval were the predominant remineralizers, provides support for the growing body of evidence regarding the crucial role of Protozoa in nutrient recycling in the epipelagic zone. Phagotrophic flagellates appear to dominate in the heterotrophic nanoplankton (Sieburth et al. 1978, Sorokin 1979, Sherr et al. 1984). However, small aloricate ciliates may prove to be more important in the future with the application of improved preservation and counting techniques (Sherr et al. 1986). The metabolic potential for the excretion of significant quantities of inorganic and organic nutrients by nanoflagellates has been clearly demonstrated in a number of microcosm studies (Sherr et al. 1983, Andersson et al. 1985, Goldman \& Caron 1985, Goldman et al. 1985). Phagotrophic nanoflagellates are regarded as the most voracious grazers of planktonic bacteria in the sea and as such provide a critical link in energy and nutrient transfer from the smallest living component of the food chain to higher trophic levels (Haas \& Webb 1979, Fenchel 1982a, Azam et al. 1983, Davis \& Sieburth 1984, Sherr et al. 1984, Andersen \& Fenchel 1985, McManus \& Fuhrman 1986). If, as discussed by Goldman \& Caron (1985), flexible feeding strategies and omnivory are common amongst nanoflagellates, they might play an imnortant additional role in recycling nuirients incorporated by photosynthetic nanoplankton, the most active primary producers in the global ocean (Malone 1980). However, the general dependence of remineralization on bacterial biomass (Fig. 9) and the positive relation between heterotrophic bacteria and heterotrophic flagellates (Sieburth \& Davis 1982, Sherr et al. 1984) provides indirect evidence for a predominantly bacterial diet for these microbes.

Paradoxically, recent laboratory experiments indicate that nanoflagellates might generally have low regeneration efficiencies. Nitrogen regeneration efficiencies of 13 to $25 \%$ have been reported for nanoflagellates fed on bacteria and phytoplankton (Andersson et al. 1985, Goldman et al. 1985). As discussed by Goldman et al. (1985) it is unlikely that a single protozoan grazing step characterized by such low regeneration efficiencies could recycle sufficient nutrients to satisfy phytoplankton requirements, or at least our present conception of the crucial importance of regenerated nutrients to phytoplankton production (Eppley \& Petersen 1979). A logical conclusion of these findings is that a number of grazing steps would be required to boost the over-all protozoan regeneration efficiency. The present results indicate that such a nanoflagellate predator would be in the same size range as bacterivorous nanoflagellates.

Netplankton ciliates $(<15 \mu \mathrm{m})$ constitute an important component of the microzooplankton community which can contribute significantly to mineral recycling in the euphotic zone. The hypotrich ciliate Euplotes vannus has been demonstrated to rapidly excrete ammonium following either an algal or bacterial meal (Gast \& Horstmann 1983). Verity (1985) has calculated for Narragansett Bay that ammonium excretion by tintinnid ciliates could supply about $18 \%$ of phytoplankton demands over the annual cycle with a maximum of $29 \%$ during the late summer. Field measurements in the Oslofjord, however, indicate that even during periods of peak abundance tintinnids accounted for $<10 \%$ of microzooplankton excretion (Paasche \& Kristiansen 1982). The accumulating evidence from laboratory experiments suggests that although weightspecific excretion rates of ciliates are considerably faster than marine crustaceans they, in turn, are much slower than for heterotrophic nanoflagellates. The clearance rates of bacterivorous ciliates are similarly 10 to 50 times slower than for phagotrophic nanoflagellates (Fenchel 1982b). Considering that microflagellates are the most dominant protozoans in the marine plankton both in terms of numbers and biomass (Sieburth et al. 1978, Davis 1982, cited in Davis \& Sieburth 1984) it appears that the contribution of large ciliates to nutrient regeneration in the field is relatively unimportant. Confirmation of this conclusion is provided by the present study in which the 15 to $200 \mu \mathrm{m}$ size interval generally contributed only a small amount to the total microplankton ammonium regeneration.

In conclusion, the present findings demonstrate that microplankton ammonium regeneration in a broad spectrum of marine environments is regulated by the concentration of particulate matter present. Remineralization increases geometrically with an increase in particulate nitrogen and decreases in an offshore direction. Generally sufficient ammonium was produced by heterotrophic microplankton to supply phytoplankton needs. Although this study did not address the larger mesozooplankton their relative contribution to community regeneration is likely to vary temporally as depicted in the model of Moloney et al. (1986), and spatially, as has been demonstrated in the western English Channel (Holligan et al. 1984b). Heterotrophic nanoplankton (mainly flagellates) appear to be the most active remineralizers in the shelf epipelagic microplankton community of the southern Benguela. It is possible that ammonium excretion by the nanoplankton fraction is the result of multiple feeding strategies amongst and predation on nanoflagellates. Direct ammonification by bacteria may be significant, espe- 
cially at depth, although generally, their more important role in the remineralization process is regarded as nourishment for bacterivorous nanoflagellates. The present size fractionation techniques, however, do not pre-empt the possibility of an enhancement of bacterial decomposition rate (and ammonium regeneration) in the presence of bacterivorous Protozoa (Barsdate et al. 1974, Fenchel \& Harrison 1976, Taylor et al. 1985). Results of this study are consistent with the new conceptual model of trophodynamics in the surface ocean in which a considerable proportion of primary production is channelled through bacterioplankton into heterotrophic nanoplankton.

Acknowledgements. I am grateful to Su Painting for her invaluable contribution to this study. I thank Professor J. G. Field, Dr M. I. Lucas and 3 anonymous referees for their constructive comments on an earlier draft of the manuscript. Mr I. Humphrey and Ms C. M. Weekley performed the bacterial and phytoplankton counts. The Department of Sea Fisheries kindly provided permission to participate in cruises aboard the research vessels 'Africana' and 'Sardinops'. This work was supported by the Phytoplankton Studies Project, Benguela Ecology Programme, SANCOR.

\section{LITERATURE CITED}

Andersen, P., Fenchel, T. (1985). Bactivory by microheterotrophic flagellates in seawater samples. Limnol. Oceanogr. 30: 198-202

Andersson, A., Lee, C., Azam, F., Hagström, А. (1985) Release of aminoacids and inorganic nutrients by heterotrophic marine microflagellates. Mar. Ecol. Prog. Ser. 23: 99-106

Azam, F., Hodson, R. E. (1977). Size distribution and activity of marine microheterotrophs. Limnol. Oceanogr. 22: 492-501

Azam, F., Fenchel, T., Field, J. G., Gray, J. S., Meyer-Reil L. A.. Thingstad, F. (1983). The ecological role of watercolumn microbes in the sea. Mar. Ecol. Prog. Ser. 10: $257-263$

Barsdate, R. J., Prentki, R. T., Fenchel, T. (1974). Phosphorus cycle of model ecosystems: significance for decomposer food chains and effect of bacterial grazers. Okkos 25: $239-251$

Bidigare, R. R. (1983). Nitrogen excretion by zooplankton. In: Carpenter, E. J., Capone, D. G. (ed.) Nitrogen in the marine environment. Academic Press, New York, p. 385-409

Bienfang, P. K., Takahashi, M. (1983). Ultraplankton growth rates in a subtropical ecosystem. Mar. Biol. 76: 213-218

Blackburn, T. H. (1979). Method for measuring rates of $\mathrm{NH}_{4}$ turnover in anoxic marine sediment, using a ${ }^{15} \mathrm{~N}-\mathrm{NH}_{4}$ dilution technique. Appl. environ. Microbiol. 37: 760-765

Caperon, J., Schell, D., Hirota, J., Laws, E. (1979). Ammonium excretion rates in Kaneohe Bay, Hawaii, measured by a ${ }^{15} \mathrm{~N}$ isotope dilution technique. Mar. Biol. 54: 33-40

Cynar, F. J., Estep, K. W., Sieburth, J. McN. (1985). The detection and characterization of bacteria-sized protists in 'protist free' filtrates and their potential impact on experimental marine ecology. Microb. Ecol. 11: 281-288
Davis, P. G. (1982). Bactivorous flagellates in marine waters. Doctoral dissertation, University of Rhode Island, Kingston

Davis, P. G., Sieburth, J. McN. (1984). Estuarine and oceanic microflagellate predation of actively growing bacteria: estimation by frequency of dividing-divided bacteria. Mar. Ecol. Prog. Ser. 19: 237-246

Doetsch, R. N., Cook, T. M. (1973). Introduction to bacteria and their ecobiology. University Park Press, Baltimore

Dugdale, R. C., Goering, J. J. (1967). Uptake of new and regenerated forms of nitrogen in primary productivity Limnol. Oceanogr. 12: 196-206

Eppley, R. W., Petersen, B. J. (1979). Particulate organic matter flux and planktonic new production in the deep ocean. Nature, Lond. 282: 677-680

Eppley, R. W., Renger, E. H., Harrison, W. G. (1979). Nitrate and phytoplankton production in southern California coastal waters. Limnol. Oceanogr. 24: 483-494

Estep, K. W., Davis, P. G., Keller, M. D., Sieburth, J. McN (1986). How important are oceanic nanoflagellates in bacterivory? Limnol. Oceanogr. 31: 646-650

Fenchel, T. (1982a). Ecology of heterotrophic microflagellates. I. Some important forms and their functional morphology. Mar. Ecol. Prog. Ser. 8: 211-223

Fenchel, T. (1982b). Ecology of heterotrophic microflagellates. II. Bioenergetics and growth. Mar. Ecol. Prog Ser. 8: 225-231

Fenchel, T., Harrison, P. (1976). The significance of bacterial grazing and mineral cycling for the decomposition of particulate detritus. In: Anderson, J. M. (ed.) The role of terrestrial and aquatic organisms in decomposition processes. Blackwell Scientific, Oxford, p. 285-299

Ferguson, R. L., Buckley, E. N., Palumbo, A. V. (1984) Response of marine bacterioplankton to differential filtration and confinement. Appl. environ. Microbiol. 47: 49-55

Fielder, R., Proksch, G. (1976). The determination of nitrogen15 by emission and mass spectrometry in biochemical analysis: a review. Analytica chim. Acta 78: 1-62

Fuhrman, J. A., McManus, G. B. (1984). Do bacteria-sized marine eukaryotes consume significant bacterial production? Science 224: $1257-1260$

Furnas, M. J. (1983). Nitrogen dynamics in lower Narragansett Bay, Rhode Island. I. Uptake by size-fractionated phytoplankton populations. J. Plankton Res. 5: 657-675

Gast, V., Horstmann, U. (1983). N-remineralization of phytoand bacterioplankton by the marine ciliate Euplotes vannus. Mar. Ecol. Prog. Ser. 13: 55-60

Glibert, P. M. (1982). Regional studies of daily, seasonal and size fraction variability in ammonium remineralization. Mar. Biol. 70: 209-222

Glibert, P. M., Lipschultz, F., McCarthy, J. J., Altabet, M. A. (1982a). Isotope dilution models of uptake and remineralization of ammonium by marine plankton. Limnol. Oceanogr. 27: 639-650

Glibert, P. M., Goldman, J. C., Carpenter, E. J. (1982b). Seasonal variations in the utilization of ammonium and nitrate by phytoplankton in Vineyard Sound, Massachusetts, USA. Mar. Biol. 70: 237-240

Goldman, J. C., Caron, D. A. (1985). Experimental studies on an omnivorous microflagellate: implications for grazing and nutrient regeneration in the marine microbial food chain. Deep Sea Res. 32: 899-915

Goldman, J. C., Caron, D. A., Andersen, O. K., Dennett, M. R. (1985). Nutrient cycling in a microflagellate food chain: I. Nitrogen dynamics. Mar. Ecol. Prog. Ser. 24: 231-242

Grasshoff, K. (1976). Methods of seawater analysis. Verlag Chemie, Weinheim 
Haas, L. W., Webb, K. L. (1979). Nutritional mode of several non-pigmented microflagellates from the York River Estuary. J. exp. mar. Biol. Ecol. 39: 125-134

Harris, E. (1959). The nitrogen cycle in Long Island Sound. Bull. Bingham oceanogr. Coll. 17: 31-65

Harrison, W. G. (1978). Experimental measurements of nitrogen remineralization in coastal waters. Limnol. Oceanogr. 23: 684-694

Harrison, W. G. (1980). Nutrient regeneration and primary production in the sea. In: Falkowski, P. G. (ed.) Primary productivity of the sea. Plenum Press, New York, p. $433-460$

Harrison, W. G. (1983). Uptake and recycling of soluble reactive phosphorus by marine microplankton. Mar. Ecol. Prog. Ser. 10: 127-135

Harrison, W. G., Azam, F., Renger, E. H., Eppley, R. W. (1977). Some experiments on phosphate assimilation by coastal marine plankton. Mar. Biol. 40: 9-18

Harrison, W. G., Douglas, D., Falkowski, P., Rowe, G., Vidal, J. (1983). Summer nutrient dynamics of the Middle Atlantic Bight: nitrogen uptake and regeneration. J. Plankton Res. 5: 539-556

Hobbie, J. E., Daley, R. J., Jasper, S. (1977). Use of nuclepore filters for counting bacteria by fluorescence microscopy. Appl. environ. Microbiol. 33: 1225-1232

Hollibaugh, J. T., Caruthers, A. B., Fuhrman, J. A., Azam, F (1980). Cycling of organic nitrogen in marine plankton communities studies in enclosed water columns. Mar Biol. 59: 15-21

Holligan, P. M., Harris, R. P., Newell, R. C., Harbour, D. S., Head, R. N., Linley, E. A. S., Lucas, M. I., Tranter, P. R. G., Weekley, C. M. (1984a). Vertical distribution and partitioning of organic carbon in mixed, frontal and stratified waters of the English Channel. Mar. Ecol. Prog. Ser. 14 $111-127$

Holligan, P. M., Williams, P. J. LeB., Purdie, D., Harris, R. P. (1984b) Photosynthesis, respiration and niirogen suppiy of plankton populations in stratified, frontal and tidally mixed shelf waters. Mar. Ecol. Prog. Ser 17: 201-213

Jeffrey, S. W., Humphrey, G. F. (1975). New spectrophotometric equations for determining chlorophylls $\mathrm{a}, \mathrm{b}, \mathrm{c}_{1}$ and $\mathrm{c}_{2}$ in higher plants, algae and natural phytoplankton. Biochem. Physiol. Pflanz. 167: 191-194

Johannes, R. E. (1965). Influence of marine protozoa on nutrient regeneration. Limnol. Oceanogr. 10: 434-442

Joint, I. R., Pomroy, A. J. (1983). Production of picoplankton and small nanoplankton in the Celtic Sea. Mar. Biol. 77: $19-27$

Koike, I., Hattori, A., Takahashi, M., Goering, J. J. (1982). The use of enclosed experimental ecosystems to study nitrogen dynamics in coastal waters. In: Brice, G. D., Reeve, M. R. (ed.) Marine mesocosms. Biological and chemical research in experimental ecosystems. Springer-Verlag, New York, p. 291-303

Krempin, D. W., McGrath, S. M., Beeler SooHoo, J., Sullivan, C. W. (1981). Orthophosphate uptake by phytoplankton and bacterioplankton from the Los Angeles Harbor and Southern California coastal waters. Mar. Biol. 64: 23-33

La Roche, J. (1983). Ammonium regeneration: its contribution to phytoplankton nitrogen requirements in a eutrophic environment. Mar. Biol. 75: 231-240

Laws, E. (1984). Isotope dilution models and the mystery of the vanishing ${ }^{15} \mathrm{~N}$. Limnol. Oceanogr. 29: 379-386

Le Bouteiller, A. (1986). Environmental control of nitrate and ammonium uptake by phytoplankton in the Equatorial Atlantic Ocean. Mar. Ecol. Prog. Ser. 30: 167-179
Lucas, M. I., Painting, S. J., Muir, D. G. (1986). Estimates of carbon flow through bacterioplankton in the S. Benguela upwelling region based on ${ }^{3} \mathrm{H}$-thymidine incorporation and predator-free incubations. GERBAM - Second International Colloquium of Marine Bacteriology - CNRS Brest, October 1984 IFREMER, Actes de Colloques, 3, p. $375-383$

Malone, T. C. (1980). Size fractionated primary productivity of marine phytoplankton. In: Falkowski, P. G. (ed.) Primary productivity in the sea. Plenum Press, New York, p. 301-320

McManus, G. B., Fuhrman, J. A. (1986). Bacterivory in seawater studied with the use of inert fluorescent particles. Limnol. Oceanogr. 31: 420-426

Moloney, C. L., Bergh, M. O., Field, J. G., Newell, R. C. (1986). The effect of sedimentation and microbial nitrogen regeneration in a plankton community: a simulation investigation. J. Plankton Res. 8: 427-445

Nalewajko, C., Garside, C. (1983). Methodological problems in the simultaneous assessment of photosynthesis and nutrient uptake in phytoplankton as functions of light intensity and cell size. Limnol. Oceanogr. 28: 591-597

Newell, R. C., Moloney, C. L., Field, J. G., Lucas, M. I., Probyn, T. A. (in press). Nitrogen cycling in coastal marine environments. 20. Nitrogen models at the community level: plant - animal - microbe interactions. Ecol. Bull.

Paasche, E., Kristiansen, S. (1982). Ammonium regeneration by microplankton in the Oslofjord. Mar. Biol. 69: 55-63

Painting, S. J., Lucas, M. I., Stenton-Dozey, J. M. E. (1985). Biomass and production of bacterioplankton in Prydz Bay, Antarctica: phytoplankton, detritus and bacterial relationships. S. Afr. J. antarct. Res. 15: 42-52

Probyn, T. A. (1985). Nitrogen uptake by size-fractionated phytoplankton populations in the southern Benguela upwelling system. Mar. Ecol. Prog. Ser 22: 249-258

Probyn, T. A., Lucas, M. I. (1987). Ammonium and phosphorus flux through the microplankton commininity in Ayuihas Bank waters. In: Payne, A. I. L., Gulland, J. A., Brink, K. H. (ed.) Benguela 86. S. Afr. J. Mar. Sci. 5: in press

Rhee, G. Y. (1972). Competition between an alga and an aquatic bacterium for phosphate. Limnol. Oceanogr. 17: 505-514

Sherr, B. F., Sherr, E. B., Berman, T. (1983). Grazing, growth, and ammonium excretion rates of a heterotrophic microflagellate fed with four species of bacteria. Appl. environ. Microbiol. 45: 1196-1201

Sherr, B. F., Sherr, E. B., Newell, S. Y. (1984). Abundance and productivity of heterotrophic namoplankton in Georgia coastal waters. J. Plankton Res. 6: 195-202

Sherr, E. B., Sherr, B. F., Fallon, R. D., Newell, S. Y. (1986). Small, aloricate ciliates as a major component of the marine heterotrophic nanoplankton. Limnol. Oceanogr. 31: $177-183$

Sieburth, J. McN., Davis, P. G. (1982). The role of heterotrophic nanoplankton in the grazing and nurturing of planktonic bacteria in the Sargasso and Caribbean Seas. Annls Inst. océanogr., Paris 58 (S): 285-296

Sieburth, J. McN., Smetacek, V., Lenz, J. (1978). Pelagic ecosystem structure: heterotrophic compartments of the plankton and their relationship to plankton size fractions. Limnol. Oceanogr. 23: 1256-1263

Sorokin, Y. I. (1979). Zooflagellates as a component of the eutrophic and oligotrophic waters in the Pacific Ocean. Oceanology 19: 316-319

Taylor, G. T. (1982). The role of pelagic heterotrophic protozoa in nutrient cycling: a review. Annls Inst. océanogr., Paris 58 (S): 227-241 
Taylor, G. T., Iturriaga, R., Sullivan, C. W. (1985). Interactions of bactivorous grazers and heterotrophic bacteria with dissolved organic matter. Mar. Ecol. Prog. Ser 23: 129-141

Verity, P. G. (1985). Grazing, respiration, excretion, and growth rates of tintinnids. Limnol. Oceanogr. 30 : 1268-1282

Williams, P. J. LeB. (1981). Incorporation of microheterotrophic processes into the classical paradigm of the planktonic food web. Kieler Meeresforsch. (Sonderh.) 5: 1-28

This article was presented by Professor R. C. Newell; it was accepted for printing on February 5, 1987 